Jurnal Inkofar * Volume 1 No. 2 Desember 2020 * ISSN: 2615-3645 (Print) / 2581-2920 (Online)

Tersedia secara online di: http://www.politeknikmeta.ac.id/meta/ojs/

\title{
UJI EFEK ANTIINFLAMASI INFUSA DAUN PURING (CODIAEUM VARIEGATUM (L.) BL.) PADA TIKUS WISTAR JANTAN
}

\author{
Farah Sulistyaningtyas
}

Program Studi Farmasi, Politeknik META Industri Cikarang, Cikarang TechnoPark Building

Jalan Inti 1 Blok C1 No 7 Lippo Cikarang Bekasi,

farahsulistyaningtyas@.politeknik.ac.id

\begin{abstract}
Research on the anti-inflammatory effect of croton infusion (Codiaeum variegatum (L.) Bl.) Infusions has been conducted on male Wistar rats. Thirty mice were then grouped into 6 groups, namely group I (negative control) given oral aquadest and $\mathrm{NaCl} 0.9 \% 0.01 \mathrm{~mL}$, group II $0.01 \mathrm{~mL}$ (positive control), group III (comparative test preparations) given diclofenac Sodium at a dose of $0.45 \mathrm{mg}$, group IV was given 10\% croton infusion, group V was given $15 \%$ croton infusion, group VI was given $20 \%$ croton infusion. The test preparation is administered orally 30 minutes before the intraplantar karagaenan is induced. Furthermore, swelling thickness was measured using a calipers from two different sides. The thickness of the swollen feet of the rat was measured once every 30 minutes and this measurement was carried out up to a time of 360 minutes. the results obtained descriptively stated that croton leaf infusion at concentrations of 10,15 and $20 \%$ did not provide anti-inflammatory effects.

Keywords: Croton leaves (Codiaeum variegatum (L.) Bl.), Anti-inflammatory, infusion, diclofenac sodium
\end{abstract}

\begin{abstract}
ABSTRAK
Telah dilakukan penelitian mengenai uji efek anti-inflamasi infusa daun puring (Codiaeum variegatum (L.) Bl.) pada tikus Wistar jantan. Sebanyak 30 ekor tikus kemudiaan dikelompokan kedalam 6 kelompok, yaitu kelompok I (kontrol negatif) diberikan aquadest oral dan diinduksi $\mathrm{NaCl}$ 0,9\% 0,01 $\mathrm{mL}$, kelompok II 0,01 $\mathrm{mL}$ (kontrol positif), kelompok III (sediaan uji pembanding) diberikan Natrium diklofenak dengan dosis $0,45 \mathrm{mg}$, kelompok IV diberikan infusa daun puring $10 \%$, kelompok $\mathrm{V}$ diberikan infusa daun puring $15 \%$, kelompok VI diberikan infusa daun puring $20 \%$. Sediaan uji tersebut diberikan terlebih dahulu secara oral 30 menit sebelum diinduksi karagaenan secara intraplantar. Selanjutnya diamati ketebanan bengkak yang diukur menggunakan alat jangka sorong dari kedua sisi yang berbeda. Ketebalan bengkak kaki tikus diukur setiap 30 menit sekali dan pengukuran ini dilakukan sampai waktu selama 360 menit. hasil yang diperoleh secara deskriptif menyatakan bahwa infusa daun puring pada konsentrasi 10, 15 dan 20\% tidak memberikan efek anti-inflamasi.

Kata kunci: Daun puring (Codiaeum variegatum (L.) Bl.), anti-inflamasi, infusa, natrium diklofenak.

\section{PENDAHULUAN}

Tanaman obat tradisonal merupakan salah satu modal dasar pembangunan kesehatan nasional. Di Indonesia disamping pelayanan kesehatan formal, pengobatan dengan cara tradisional dan pemakaian obat tradisional masih banyak dilakukan oleh masyarakat secara luas, baik di daerah pedesaan maupun daerah perkotaan (Hargono, 1986). Tiap-tiap tumbuhan bila diselidiki dan dipelajari maka akan diketahui kegunaanya. Penduduk desa jauh dari kota dan tidak mudah mendapatkan obat yang diperlukan, maka mereka memanfaatkan tumbuh- tumbuhan sebagai obat (Atjung, 1982).
\end{abstract}

(C) 2020, Jurnal InkofarAll Rights Reserved 
Tanaman puring secara empiris memiliki efek analgetik. Selain mempunyai efek analgetik daun puring mempunyai khasiat sebagai karminatif dan obat mulas berdasarkan kandungan kimia yang terdapat pada daunya yaitu, mengandung saponin, flavonoid, tanin, dan minyak aksiri. Selain itu efek farmakologi disebutkan tanaman ini memiliki rasa pahit, dingin, beracun. Tanaman puring berkhasiat melancarkan peredaran darah, peluruh keringat dan pencahar ringan. Akar dan kulit batang mempunyai rasa pedas, yang berkurang bila digodok bersama dengan scutellaria. Efek farmakologi ini diperoleh dari penggunaan daun, ranting muda, akar dan kulit batang.

Pada penelitian ini ingin diketahui apakah ekstrak daun puring mempunyai efek antiinflamasi pada tikus putih jantan Galur Wistar jantan sebagai aktivitas antiradang yang bertujuan menghambat pembentukan udem yang diinduksi pada kaki tikus. Metodelogi yang digunakan pada penelitian ini adalah Metode uji dilakukan dengan pembentukan udem pada kaki tikus yang diinduksi suspensi karagenan 1\% dalam air suling secara intraplantar, Pengukuran udem kaki tikus dilakukan dengan alat pletismometer yang bekerja berdasarkan hukum Archimedes. Diharapkan penelitian dengan Metodelogi ini dapat memberikan informasi berdasar fakta ilmiah kepada masyarakat bahwa ekstrak air daun puring dapat menghambat pembentukan udem sebagai antiinflamasi.

\section{METODE PENELITIAN}

Jenis penelitian eksperimental semu, yaitu mengamati kemungkinan pengaruh diantara variabel dengan melakukan pengamatan terhadap kelompok eksperimental semu pada berbagai kondisi perlakuan dan membandingkan dengan kelompok kontrol. Penelitian ini menggunakan rancangan acak lengkap pola searah. Pada uji antiinflamasi hewan yang digunakan adalah tikus yang peka terhadap rangsangan nyeri. Sebelum digunakan tikus dipuasakan selama kurang lebih 18 jam, tapi minum tetap diberikan. Mencit ditimbang dan dikelompokkan secara acak menjadi 5 kelompok, setiap kelompok terdiri dari 5 ekor hewan percobaan. Tikus diberi perlakuaan sesuai dengan kelompoknya. Hewan uji yang digunakan adalah tikus putih jantan galur Wistar sebanyak 25 ekor, semua hewan uji dipelihara dalam kondisi yang sama. Hewan uji dibagi menjadi 5 kelompok. Sebelum diberi perlakuan, kaki tikus ditandai, kemudian diukur volumenya. Volume kaki tikus diukur dengan menggunakan pletismometer dengan cara mencelupkan kaki tikus yang sudah ditandai ke dalam raksa yang ada dalam pletismometer. Perlakuan dengan sediaan uji yang diberikan secara per oral pada masing masing kelompok adalah:

Kelompok I : akuades $2,5 \mathrm{ml} / 200$ gramBB (kontrol negatif)

Kelompok II : Natrium diklofenak dosis $2,25 \mathrm{mg} / \mathrm{kgBB}$ (kontrol positif)

Kelompok III : ekstrak etanol daun puring dosis $490 \mathrm{mg} / \mathrm{KgBB}$

Kelompok IV : ekstrak etanol daun puring dosis $245 \mathrm{mg} / \mathrm{KgBB}$

Kelompok V : ekstrak etanol daun puring dosis $123 \mathrm{mg} / \mathrm{KgBB}$

Perlakuan ini dilakuan 1 jam sebelum induksi karagenin 1\%. Induksi dilakukan pada kaki tikus secara subplantar. Setelah semua tikus diinduksi, kemudian diukur volume kaki tikus setiap $0,5 \mathrm{jam}$. Pengukuran dilakukan selama 6,5jam.

\subsection{Analisis Data}

Data yang diperoleh berupa volume kaki tikus, kemudian digunakan untuk menghitung volume udem. Volume udem merupakan selisih kaki tikus sebelum dan sesudah diradangkan dengan rumus:

$$
\mathrm{Vu}=\mathrm{Vt}-\mathrm{Vo}
$$

Keterangan :

$\mathrm{Vu} \quad$ : volume udem kaki tikus tiap waktu

$\mathrm{Vt}$ : volume kaki tikus setelah diradangkan karaqgenin $1 \%$ pada waktu $\mathrm{t}$

Vo : volume kaki tikus sebelum diradangkan karagenin 1\% 
Setelah diperoleh diperoleh kurva volume udem kaki tikus vs waktu, selanjutnya digunakan untuk menghitung AUC (Area Under the Curve), kurva antara rata-rata volume udem terhadap waktu.

Rumus yang digunakan untuk menghitung $\mathrm{AUC}_{t n-1}^{t n}$ adalah

$$
\text { AUCtm-1 }=\frac{V t n-1+V}{2}(\text { tn-tn-1) }
$$

Keterangan:

$V t_{n-1}=$ rata-rata volume udem pada $t_{n-1}$

$V t_{n} \quad=$ rata-rata volume udem pada $t_{n}$

Prosentase daya antiinflamasi (penghambatan volume udem) dihitung berdasarkan harga AUC kontrol negatif dan harga AUC perlakuan pada tiap individu menggunakan rumus berikut :

$$
\% \mathrm{DAI}=\frac{A U C k \quad A U C p}{A U C k} \times 100 \%
$$

Keterangan:

$\%$ DAI = Persen daya antiinflamasi

$\mathrm{AUC}_{\mathrm{k}}=\mathrm{AUC}$ rata-rata kurva volume udem terhadap waktu untuk kontrol negatif

$\mathrm{AUC}_{\mathrm{p}}=\mathrm{AUC}$ rata-rata kurva volume udem terhadap waktu untuk kelompok perlakuan pada tiap individu.

Data AUC (Area Under the Curve) antara volume udema terhadap waktu dilakukan uji Kolmogorof-Smirnov guna mengetahui distribusi data dan Levene Statistic test untuk mengetahui homogenitas variannya. Apabila terdistribusi normal dan homogen dilanjutkan dengan analisis varian satu jalan (Oneway Anova) dengan taraf kepercayaan 95\% dan dilanjutkan uji LSD (Least Significant Difference) untuk mengetahui ada atau tidaknya perbedaan bermakna. Analisis data dikerjakan dengan Program SPSS versi 14.

\section{HASIL DAN PEMBAHASAN}

3.1. Hasil Determinasi Tanaman

Daun puring yang diambil dari kebun percobaan Manoko, Lembang, Jawa Barat (1.200m dpl). Kemudian dilakukan determinasi di SITH-ITB untuk mengetahui kebenaran dari daun puring tersebut. Hasil determinasi tanaman menunjukkan bahwa tanaman yang digunakan adalah benar tanaman daun puring ( Codiadeum Variegatum (L). Bl ). Tujuan determinasi sendiri adalah untuk mengetahui kebenaran bahan uji yang akan digunakan.

\subsection{Hasil Penapisan Fitokimia}

Terhadap daun puring dilakukan penetapan kadar air, kadar abu total dan penapisan fitokimia. Ketiga pengujian ini sering dilakukan untuk mengetahui karakteristik suatu simplisia yang digunakan untuk bahan penelitian, karena dengan ketiga parameter ini kita bisa memprediksi kualitas simplisia yang kita gunakan untuk penelitian. Penapisan fitokimia atau skrining fitokimia merupakan tahapan awal dalam mengidentifikasi golongan senyawa metabolit sekunder yang terkandung dalam daun puring ( Codiadeum Variegatum (L). Bl ). Penapisan fitokimia dilakukan terhadap simplisia dan infusa daun puring. Penapisan fitokimia terhadap infusa daun puring bertujuan untuk mengetahui pengaruh metode infus yang digunakan dalam 
menarik metabolit sekunder yang terkandung dalam simplisia. Hasil penapisan fitokimia dapat dilihat pada Tabel III.2

Tabel III.2 Hasil penapisan fitokimia terhadap simplisia dan Infus daun puring (Codiadeum Variegatum $(\mathrm{L})$. Bl )

\begin{tabular}{|c|c|c|}
\hline \multirow{2}{*}{ Golongan Senyawa } & \multicolumn{2}{|c|}{ Hasil } \\
\hline & simplisia & Infus \\
\hline Alkaloid & + & + \\
\hline Flavonoid & + & + \\
\hline Saponin & - & - \\
\hline Quinon & + & + \\
\hline steroid \& triterpenoid & + & + \\
\hline Tanin & + & + \\
\hline
\end{tabular}

Keterangan :

$(+)$ : terdeteksi
$(-)$ : tidak terdeteksi

Tabel III.2 menunjukan bahwa hasil penapisan fitokimia simplisia dan infus yaitu sama. Mengandung alkaloid, flavonoid, quinon, steroid dan triterpenoid serta tanin. Hal ini menunjukan bahwa senyawa metabolit sekunder yang terdapat dalam simplisia daun puring terekstraksi dengan baik oleh pelarut air.

\subsection{Hasil Penetapan Kadar Air, Kadar Abu Total}

Pada hasil pengujian menunjukan bahwa kadar air simplisia daun puring yaitu sebesar 3,33\%. Hasil tersebut telah memenuhi standar syarat penentuan kadar air simplisia yaitu $\leq 10 \%$ (Depkes RI, 1989:7).

Penetapan kadar air bertujuan untuk mengetahui kualitas simplisia, karena kadar air yang tinggi merupakan media yang baik untuk pertumbuhan mikroba dan mempercepat proses pembusukan pada simplisia sehingga khasiatnya dapat menurun ( Depkes RI, 1989:8). Hasil pemeriksaan kadar abu total dari daun puring yaitu sebesar $6.35 \%$. Kadar abu total menunjukan kandungan mineral dan senyawa anorganik yang ada pada simplisia ( Depkes RI, 1989:45).

\subsection{Hasil Infus}

Simplisia yang digunakan merupakan daun puring yang sudah diperoleh dicuci bersih lalu dikeringkan pada suhu ruangan. Daun puring kemudian dihaluskan menjadi bentuk serbuk dan kemudian ditimbang sampai 10 gram.

Pembuatan infus yang digunakan dengan konsentrasi dosis $10 \%, 15 \%$ dan 20\% b/v. 10 gram daun puring yang sudah halus ditambahkan $100 \mathrm{ml}$ air suling. Selanjutnya dipanaskan sampai pada suhu $90^{\circ} \mathrm{C}$ selama 15 menit. Infus diserkai selagi panas dengan kain flanel, kemudian ditambahkan air hangat sampai diperoleh volume $100 \mathrm{ml}$ pada masing-masing konsentrasi dosis tersebut.

\subsection{Hasil Uji Pendahuluan}

Uji pendahuluan dilakukan untuk mengetahui efektifitas dosis induktor karagenan $1 \%$ yang akan digunakan dalam pembentukan udem pada pada kaki tikus yang dibandingkan dengan dosis larutan $\mathrm{NaCl} \quad 0.9 \%$ yang sama-sama diberikan $0.001 \mathrm{ml}$ secara intrakutan. Hasil uji pendahuluan dapat dilihat pada Tabel III.5. 
Jurnal Inkofar * Volume 1 No. 2 Desember 2020 * ISSN: 2615-3645 (Print) / 2581-2920 (Online)

Tersedia secara online di: http://www.politeknikmeta.ac.id/meta/ojs/

Tabel III.5 Perbandingan Ketebalan Udem Kontrol Positif dan Kontrol Negatif

Ketebalan Bengkak

\begin{tabular}{ccc} 
Waktu ( Menit) & kontrol $(-)$ & Kontrol $(+)$ \\
\hline 0 & 0.00 & 0.56 \\
\hline 30 & 0.00 & 0.65 \\
\hline 60 & 0.00 & 0.79 \\
\hline 90 & 0.00 & 0.87 \\
\hline 120 & 0.00 & 0.98 \\
\hline 150 & 0.00 & 0.87 \\
\hline 180 & 0.00 & 0.75 \\
\hline 210 & 0.00 & 0.69 \\
\hline 240 & 0.00 & 0.00 \\
\hline
\end{tabular}

Dilihat dari Tabel III.5 menunjukan bahwa tikus yang diberikan induktor karagenan 1\% dapat menyebabkan udem lebih lama dibandingkan dengan tikus yang diberikan $\mathrm{NaCl} 0.9 \%$. Induktor karagenan 1\% dapat menyebabkan bengkak selama 210 menit. Sedangkan yang hanya diberikan larutan $\mathrm{NaCl} 0.9 \%$ tidak menyebabkan udem. Hal ini terjadi karena pada injeksi karagenan tersebut terjadi perubahan inflamasi berupa peningkatan opioid peptida dan marker transkripsi (Bruera dan Portenoy, 2003). Inflamasi yang diinduksi oleh karagenan dengan peningkatan rasa sakit, pembengkakan, dan sintesis prostaglandin hingga 4-5 kali (Tsokos, 2002). Setiap ada cedera, terjadi rangsangan untuk dilepaskannya zat kimia tertentu yang akan menstimulasi terjadinya perubahan jaringan pada reaksi radang tersebut diantaranya adalah histamin, serotonin, bradikinin, leukotrien, dan prostaglandin. Histamin bertanggung jawab pada perubahan yang paling awal yaitu menyebabkan vasodilatasi pada arteriol yang didahului dengan vasokontriksi awal dan peningkatan permeabilitas kapiler. Hal ini menyebabkan perubahan distribusi sel darah merah. Oleh karena aliran darah yang lambat, sel darah merah akan menggumpal, akibatnya sel darah putih terdesak kepinggir. Makin lambat aliran darah maka sel darah putih akan menempel pada dinding pembuluh darah dan makin lama akan semakin banyak. Perubahan permeabilitas yang terjadi menyebabkan cairan keluar dari pembuluh darah dan berkumpul dalam jaringan. Bradikinin bereaksi lokal menimbulkan rasa sakit, vasodilatasi, meningkatkan permeabilitas kapiler. Sebagai penyebab radang, prostaglandin berpotensi kuat setelah bergabung dengan mediator lainnya (Mansjoer, 1999 : 34).

Uji pendahuluan dilakukan untuk menentukan dosis infus daun puring yang dapat menurunkan udem pada kaki tikus karena dosis empiris yang tidak diketahui. Berdasarkan percobaan, infus daun puring memiliki kelarutan yang baik didalam air. Oleh karena itu, untuk meningkatkan penetrasi sediaan uji ke dalam kaki tikus maka daun puring diformulasikan dalam bentuk sediaan cair yang diperoleh dari hasil Infus.

Infus adalah sediaan cair yang dibuat dengan cara menyari simplisia nabati dengan air pada suhu $90^{\circ} \mathrm{C}$ selama 15 menit (Departemen Kesehatan Republik Indonesia, 1979). Infus diberikan secara oral pada tikus yang telah diinduktor karagenan $1 \%$. Infus daun puring dibuat dalam tiga variasi dosis yaitu $10 \%$ untuk dosis I, $15 \%$ untuk dosis II dan $20 \%$ untuk dosis III. Hasil pengamatan uji pendahuluan sediaan uji dapat dilihat pada Tabel III.6. 
Tabel III.6 Hasil Uji pendahuluan Sediaan Uji Dosis I, Dosis II dan Dosis III

\begin{tabular}{ccccc}
\hline & \multicolumn{4}{c}{ Ketebalan udem } \\
\cline { 2 - 5 } $\begin{array}{c}\text { Waktu } \\
\text { ( Menit) }\end{array}$ & $\begin{array}{c}\text { Kontrol } \\
(+)\end{array}$ & Dosis I & Dosis II & Dosis III \\
\hline 0 & 0.56 & 0.89 & 0.78 & 0.62 \\
\hline 30 & 0.65 & 1.80 & 1.62 & 1.54 \\
\hline 60 & 0.79 & 1.71 & 1.50 & 0.50 \\
\hline 90 & 0.87 & 1.61 & 0.42 & 0.43 \\
\hline 120 & 0.98 & 0.52 & 0.43 & 0.00 \\
\hline 150 & 0.87 & 0.50 & 0.00 & 0.00 \\
\hline 180 & 0.75 & 0.41 & 0.00 & 0.00 \\
\hline 210 & 0.69 & 0.00 & 0.00 & 0.00 \\
\hline 240 & 0.00 & 0.00 & 0.00 & 0.00 \\
\hline
\end{tabular}

Dari data pengamatan diatas terlihat bahwa sediaan uji dosis I telah memberikan efek menurunkan ketebalan udem lebih cepat dibandingkan dengan kaki tikus yang tidak diberikan sediaan uji. Sediaan uji dosis I membutuhkan waktu 210 menit untuk menurunkan ketebalan udem sampai ke kondisi normal, sedangkan kaki tikus yang tidak diberikan sediaan uji membutuhkan waktu 240 menit untuk menurunkan ketebalan udem sampai pada kondisi normal. Sediaan uji dosis II membutuhkan waktu 150 menit untuk menurunkan ketebalan udem dan pada uji dosis III memerlukan waktu 120 menit untuk menurunkan ketebalan udem sampai ke kondisi normal, pada uji dosis III lebih cepat menurunkan ketebalan udem. karena, isi kandungan senyawa flavonoid pada infus yang terdapat dalam sediaan uji dosis III lebih banyak. Pada tikus yang diberikan sediaan uji, penurunan ketebalan udem setiap tikus diduga dipengaruhi oleh pertahanan tubuh tikus dan senyawa metabolit sekunder yang terkandung dalam infus daun puring yaitu alkaloid, flavonoid, quinon, steroid dan triterpenoid serta tanin.

\subsection{Hasil Pengujian Efek Antiinflamasi}

Induksi udem dilakukan secara kimia dengan menggunakan karagenan 1\% (b/v) $0.001 \mathrm{ml}$ yang disuntikan secara intrakutan pada kaki tikus. Penggunaan karagenan sebagai penginduksi udem memiliki beberapa keuntungan antara lain tidak meninggalkan bekas, tidak menimbulkan kerusakan jaringan dan memberikan respon yang lebih peka terhadap obat antiinflamasi dibandingkan senyawa iritan lainnya. Udem yang disebabkan induksi karagenan dapat bertahan maksimal selama 360 menit dan berangsur-angsur berkurang dalam waktu 24 jam (Patimah, 2010: 12-13). Namun, setelah karagenan disuntikan secara intrakutan, kaki tikus mengalami udem kemudian setiap menit mengalami penurunan udem. Hal ini terjadi karena pertahanan tubuh tikus ikut berperan dalam menurunkan udem.

Data yang diperoleh dianalisis dengan analisis variasi (ANOVA) menggunakan bantuan program SPSS versi 17. Untuk melihat perbedaan efek antara dua kelompok secara berpasangan maka dilakukan uji LSD.

Hasil pengamatan rataan ketebalan udem dan signifikansi antara kelompok kontrol dan sediaan uji dapat dilihat pada Tabel III.4. 
Jurnal Inkofar * Volume 1 No. 2 Desember 2020 * ISSN: 2615-3645 (Print) / 2581-2920 (Online)

Tersedia secara online di: http://www.politeknikmeta.ac.id/meta/ojs/

Tabel III.4. Hasil Rataan Ketebalan Udem Kelompok Kontrol dan Sediaan Uji.

\begin{tabular}{|c|c|c|c|c|c|c|c|}
\hline \multirow{2}{*}{$\begin{array}{l}\text { Waktu } \\
\text { (Menit) }\end{array}$} & \multicolumn{7}{|c|}{ Ketebalan Udem $(\mathrm{cm}) \pm$ Standar Deviasi } \\
\hline & Kontrol & Dosis I & $\mathrm{P}$ & Dosis II & $\mathrm{P}$ & Dosis III & $\mathrm{P}$ \\
\hline 0 & $\begin{array}{c}0.4560 \pm \\
0.15128\end{array}$ & $\begin{array}{c}0.6020 \pm \\
0.21615\end{array}$ & 0.151 & $\begin{array}{l}1.3720 \pm \\
0.12755\end{array}$ & 0.400 & $\begin{array}{r}0.5440 \pm \\
0.10139 \\
\end{array}$ & 0.379 \\
\hline 30 & $\begin{array}{c}0.5940 \pm \\
0.16965\end{array}$ & $\begin{array}{c}1.4000 \pm \\
0.54240\end{array}$ & $0.000 *$ & $\begin{array}{l}1.5280 \pm \\
0.12755\end{array}$ & $0.000^{*}$ & $\begin{array}{r}1.5740 \pm \\
0.10383 \\
\end{array}$ & $0.000^{*}$ \\
\hline 60 & $\begin{array}{c}0.6120 \pm \\
0.13405\end{array}$ & $\begin{array}{l}1.5400 \pm \\
0.54093\end{array}$ & $0.000^{*}$ & $\begin{array}{r}1.6600 \pm \\
0.09028 \\
\end{array}$ & $0.000^{*}$ & $\begin{array}{r}1.6620 \pm \\
0.09960 \\
\end{array}$ & $0.000^{*}$ \\
\hline 90 & $\begin{array}{c}0.7900 \pm \\
0.15133 \\
\end{array}$ & $\begin{array}{l}1.7360 \pm \\
0.04506 \\
\end{array}$ & $0.000^{*}$ & $\begin{array}{r}1.7940 \pm \\
0.11653 \\
\end{array}$ & $0.000^{*}$ & $\begin{array}{r}0.6320 \pm \\
0.08899 \\
\end{array}$ & $0.030^{*}$ \\
\hline 120 & $\begin{array}{c}0.7760 \pm \\
0.12992 \\
\end{array}$ & $\begin{array}{l}1.8140 \pm \\
0.09737\end{array}$ & $0.000^{*}$ & $\begin{array}{r}1.8900 \pm \\
0.08746 \\
\end{array}$ & $0.000^{*}$ & $\begin{array}{r}1.6380 \pm \\
0.12050 \\
\end{array}$ & $0.000 *$ \\
\hline 150 & $\begin{array}{c}0.6960 \pm \\
0.12341\end{array}$ & $\begin{array}{l}1.6880 \pm \\
0.16037\end{array}$ & $0.000^{*}$ & $\begin{array}{r}1.8240 \pm \\
0.08503\end{array}$ & $0.000^{*}$ & $\begin{array}{c}1.4160 \pm \\
0.42741\end{array}$ & $0.002 *$ \\
\hline 180 & $\begin{array}{c}0.6340 \pm \\
0.18929 \\
\end{array}$ & $\begin{array}{l}1.6600 \pm \\
0.10977 \\
\end{array}$ & $0.000^{*}$ & $\begin{array}{r}1.6800 \pm \\
0.10863 \\
\end{array}$ & $0.000^{*}$ & $\begin{array}{c}0.00000 \pm \\
0.0000 \\
\end{array}$ & $0.000^{*}$ \\
\hline 210 & $\begin{array}{c}0.6540 \pm \\
0.14843 \\
\end{array}$ & $\begin{array}{l}1.7100 \pm \\
0.11726\end{array}$ & $0.000^{*}$ & $\begin{array}{r}0.0000 \pm \\
0.00000\end{array}$ & $0.000^{*}$ & $\begin{array}{c}0.00000 \pm \\
0.0000\end{array}$ & $0.000 *$ \\
\hline 240 & $\begin{array}{c}0.5200 \pm \\
0.10607\end{array}$ & $\begin{array}{c}0.0000 \pm \\
0.00000\end{array}$ & $0.000^{*}$ & $\begin{array}{c}0.00000 \pm \\
0.00000\end{array}$ & $0.000 *$ & $\begin{array}{c}0.00000 \pm \\
0.0000\end{array}$ & $0.000^{*}$ \\
\hline
\end{tabular}

Keterangan:

$\mathbf{P}=$ Signifikasi perbedaan ketebalan udem antara kelompok uji dengan kelompok kontrol

*.= Perbedaan bermakna antara kelompok uji dengan kelompok kontrol.

Dilihat dari Tabel III.4 menunjukan pada menit ke-0 antara kelompok kontrol positif dengan sediaan uji dosis I terlihat tidak ada perbedaan bermakna dengan $\mathrm{P}=0.151$. Selanjutnya pada menit ke-30 sampai menit ke-240 antara kelompok kontrol positif dengan sediaan uji dosis I terlihat adanya perbedaan yang bermakna dengan $\mathrm{P}=0.000$. Oleh karena itu, kemungkinan efek antiinflamasi yang diberikan pada sediaan uji dosis I mulai dicapai pada menit ke-30 dan membutuhkan waktu 240 menit untuk menurunkan ketebalan udem sampai pada kondisi normal.

Pada menit ke-0 antara kelompok kontrol positif dengan sediaan uji dosis II terlihat tidak ada perbedaan bermakna dengan $\mathrm{P}=0.400$. Selanjutnya pada menit ke-30 sampai menit ke-240 antara kelompok kontrol positif dengan sediaan uji dosis II terlihat adanya perbedaan yang bermakna dengan $\mathrm{P}=0.000$. Oleh karena itu, kemungkinan efek antiinflamasi yang diberikan pada sediaan uji dosis II mulai dicapai pada menit ke-30 dan membutuhkan waktu 210 menit untuk menurunkan ketebalan udem sampai pada kondisi normal.

Pada menit ke-0 antara kelompok kontrol positif dengan sediaan uji dosis III terlihat tidak ada perbedaan bermakna dengan $\mathrm{P}=0.379$. Selanjutnya pada menit ke-30 sampai menit ke-60 dan menit ke-120 antara kelompok kontrol positif dengan sediaan uji dosis III terlihat adanya perbedaan yang bermakna dengan $\mathrm{P}=0.000$. kemudian, pada menit ke- 90 dan menit ke- 150 antara kelompok kontrol positif dengan sediaan uji dosis III terlihat ada perbedaan bermakna dengan $\mathrm{P}=0.030$ dan $\mathrm{P}=0.002$. hal ini disebabkan karena pembentukan ketebalan udem awal pada tiap tikus yaitu berbeda. Oleh karena itu, kemungkinan efek antiinflamasi yang diberikan pada sediaan uji dosis III mulai dicapai pada menit ke-30 dan membutuhkan waktu 120 menit untuk menurunkan ketebalan udem sampai pada kondisi normal.

Dari data diatas dapat disimpulkan bahwa peningkatan dosis berbanding lurus dengan penurunan ketebalan bengkak pada kaki tikus, dan secara umum efek antiinflamasi tercapai pada menit ke-30. Hal ini disebabkan pada infus daun puring mengandung alkaloid, flavonoid, 
quinon, steroid dan triterpenoid serta tanin yang diduga mampu menghambat pembentukan radang.

Daun puring memiliki kandungan flavonoid terbanyak jika dibandingan dengan daun yang lainnya, selain itu kandungan daun puring memiliki kadar klorofil dalam jumlah yang tinggi, baik daun muda dan daun tua (Loveless, A. R. 1987). Selain itu menurut Robinson, flavonoid dalam dalam tubuh dapat bertindak sebagai menghambat lipooksigenase yang berperan dalam biosintesis pembentukan radang.

Selain itu uji LSD dilakukan untuk melihat ada tidaknya perbedaan karagenan sebagai kontrol positif dengan Natriumdiklofenak $2.25 \mathrm{mg}$ sebagai pembanding. Hasil pengamatan rataan ketebalan bengkak antara kelompok kontrol dan pembanding dapat dilihat pada Tabel III.5.

Tabel .5. Hasil Rataan Ketebalan Udem Kelompok Kontrol dan Pembanding

\begin{tabular}{cccc}
\hline \multirow{2}{*}{ Waktu ( Menit) } & \multicolumn{3}{c}{ Ketebalan Udem $(\mathrm{cm}) \pm$ Standar Deviasi } \\
\cline { 2 - 4 } & Kontrol & Pembanding & $\mathrm{P}$ \\
\hline 0 & $0.4560 \pm 0.15128$ & $0.5200 \pm 0.15281$ & 0.520 \\
\hline 30 & $0.5940 \pm 0.16965$ & $0.6280 \pm 0.12050$ & 0.844 \\
\hline 60 & $0.6120 \pm 0.13405$ & $0.7100 \pm 0.10954$ & 0.559 \\
\hline 90 & $0.7900 \pm 0.15133$ & $0.8040 \pm 0.10213$ & 0.838 \\
\hline 120 & $0.7760 \pm 0.12992$ & $1.0420 \pm 0.44963$ & 0.075 \\
\hline 150 & $0.6960 \pm 0.12341$ & $1.1920 \pm 0.55278$ & $0.027^{*}$ \\
\hline 180 & $0.6340 \pm 0.18929$ & $1.7040 \pm 0.12973$ & $0.000^{*}$ \\
\hline 210 & $0.6540 \pm 0.14843$ & $1.6280 \pm 0.8786$ & $0.000^{*}$ \\
\hline 240 & $0.5200 \pm 0.10607$ & $0.0000 \pm 0.00000$ & $0.000^{*}$ \\
\hline
\end{tabular}

Keterangan :

$\mathbf{P}=$ Signifikasi perbedaan ketebalan udem antara kelompok kontrol dengan pembanding

*.= Perbedaan bermakna antara kelompok kontrol dengan pembanding.

Pada menit ke-0 sampai menit ke-120 menunjukan tidak ada perbedaan bermakna yang signifikan antara kelompok kontrol positif dengan pembanding ( $\mathrm{P}>0.05)$. hal ini terjadi karena pertahanan tubuh tikus ikut berperan dalam menurunkan ketebalan udem. pada menit ke-150 menunjukan nilai signifikan $\mathrm{P}=0.027$ dan pada menit ke-180 sampai 240 menunjukan nilai signifikan $\mathrm{P}=0.000$ antara kelompok kontrol dengan pembanding. Hal ini menunjukan ada perbedaan bermakna antara kelompok kontrol positif dengan pembanding sehingga dapat disimpulkan bahwa metode yang digunakan adalah valid. Pengujian efek antiinflamasi ini dilakukan dengan menggunakan pengukuran manual dari kedua sisi yang berbeda pada kaki tikus dengan menggunakan jangka sorong, kemudian dirata-ratakan dari hasil data yang diperoleh dari tiap masing-masing kelompok uji, kemudian dianalisa menggunakan ANOVA.

\section{KESIMPULAN DAN SARAN}

\subsection{Kesimpulan}

Infusa daun puring pada konsentrasi dosis $10 \%, 15 \%$ dan $20 \%$ terlihat ada perbedaan yang bermakna dengan kontrol pada mulai menit ke-30 $(\mathrm{P}=0.000)$ dan penurunan ketebalan udem terbesar dicapai pada menit ke-240 untuk infus daun puring $10 \%(\mathrm{P}=0.000)$. Sedangkan penurunan ketebalan udem untuk infus daun puring $15 \%(\mathrm{P}=0.000)$ dicapai pada menit ke-210. Dan penurunan ketebalan udem untuk infus daun puring $20 \%(\mathrm{P}=0.000)$ dicapai pada menit ke180. Sehingga dapat disimpulkan bahwa infus daun puring pada dosis $10 \%, 15 \%$ dan $20 \%$ memiliki efek antiinflamasi. Infus daun puring pada dosis $15 \%$ dan $20 \%$ memiliki efek antiinflamasi lebih cepat dibandingkan dengan kelompok kontrol. 


\subsection{Saran}

Perlu dilakukan penelitian lebih lanjut untuk uji efek antiinflamasi dengan metode yang berbeda dan zat aktif yang berkhasiat sebagai antiinflamasi yang terkandung dalam infus daun puring serta pengujian terhadap uji toksisitas untuk mengetahui keamanan pemakaiannya dalam jangka waktu yang lama.

\section{DAFTAR PUSTAKA}

Atjung., (1982)., Teknologi Farmasi, Jakarta : PT. Kompas media Nusantara Backer. C. A \& Bakhuizen van den Brink, Jr., R., C., 1963. Flora of Java Volume

1. N. V. P. Noordhoff-Groningen, the Netherlands.

Bruera, E, and Portenoy, R.K. (2003). Cancer Pain : Assessment and Managemen, Cambridge. Cambridge University Press.

Danarti dan Sri Najiyati, 1998. Tanaman Hias, Budidaya dan Analisis Usaha Tani. Penerbit : Swadaya, Jakarta. 